\title{
GENETIC POLYMORPHISMS OF OROSOMUCOID AND ALPHA-2-HS-GLYCOPROTEIN IN THAI, SRI LANKAN AND PARAGUAYAN POPULATIONS
}

\author{
Kazuo Umetsu, ${ }^{1}$ Isao Yuasa, ${ }^{2}$ Takao Yamashita, ${ }^{3}$ Susumu Saito, ${ }^{3}$ \\ Tomio Yamaguchi, ${ }^{4}$ Srinama B. Ellepola, ${ }^{5}$ Takafumi Ishida, ${ }^{6}$ \\ and Tsuneo SUZUKI ${ }^{1}$ \\ ${ }^{1}$ Department of Forensic Medicine, Yamagata University School of Medicine, \\ Yamagata 990-23, Japan \\ ${ }^{2}$ Department of Legal Medicine, Tottori University School of Medicine, \\ Yonago 683, Japan \\ ${ }^{3}$ Department of Parasitology, Yamagata University School of Medicine, \\ Yamagata 990-23, Japan \\ ${ }^{4}$ Department of Parasitology, Hirosaki University School of Medicine, \\ Hirosaki 036, Japan \\ ${ }^{5}$ Department of Medicine, Faculty of Medicine, University of Peradeniya, \\ Peradeniya, Sri Lanka \\ ${ }^{6}$ Department of Biochemistry, Primate Research Institute, Kyoto University, \\ Inuyama 484, Japan
}

\begin{abstract}
Summary The genetic polymorphism of orosomucoid (ORM) and alpha2-HS-glycoprotein (AHSG) were studied in Thai, Sri Lankan and Paraguayan populations using isoelectric focusing. Gene frequencies in these populations were compared with those in other populations. Four new ORM variants were detected: $O R M I^{*} 15$ in Thai, $O R M I^{*} 16$ in Paraguayan, $O R M 2 * 21$ and $O R M 2 * 22$ in Sri Lankan.
\end{abstract}

Key Words polymorphism, serum type, ORM1, ORM2, AHSG

\section{INTRODUCTION}

Genetic polymorphism of human serum orosomucoid (ORM) was described by Johnson et al. (1969) using agarose gel electrophoresis followed by immunofixation. ORM polymorphisms have recently been studied using isoelectric focusing (IEF), and some variant alleles have been reported at two structural loci, ORM1 and ORM2 (Tsuge et al., 1987; Weidinger et al., 1987; Yuasa et al., 1988; Umetsu et al., 1989). In ORM1 locus, two duplicated alleles $\left(O R M I^{* 2 \cdot 1}\right.$ and $O R M I^{* 5 \cdot 2)}$ have also been described (Yuasa et al., 1987, 1988). The detection of the variant alleles are

Received June 19, 1989 ; revised version received July 17, 1989; Accepted July 18, 1989. 
mainly due to the high resolving power of IEF in polyacrylamide gels containing Triton X-100 (Umetsu et al., 1987).

Alpha-2-HS-glycoprotein (AHSG) polymorphism was first described by Anderson and Anderson (1977) using two-dimensional electrophoresis. Cox and Andrews (1983) and Umetsu et al. (1983) applied one-dimensional IEF to AHSG phenotyping and confirmed two common alleles $\left(A H S G^{*} I\right.$ and $\left.A H S G^{*} 2\right)$. Since then, several variants have been identified, as summarized by Yuasa and Umetsu (1988).

The population studies of genetic polymorphisms of ORM and AHSG have been reported, and several alleles were known as specific genetic markers: $O R M 1^{*} 3$ and $A H S G^{*} 3$ are for Caucasians, $O R M 2^{*} 6$ for Mongoloids, $A H S G^{*} 5$ for Japanese, and $A H S G^{*} 10$ for Blacks.

In the present work, we report distributions of ORM1, ORM2 and AHSG allele frequencies in Thai, Sri Lankan and Paraguayan populations and four new ORM variants were found in these populations.

\section{MATERIALS AND METHODS}

Serum samples of 709 unrelated individuals from three populations (369 from Thai, Chiang Rai; 140 from Sri Lankan, Peradeniya; 200 from Paraguayan, Asuncion) were tested for ORM and AHSG typing. The ORM typing was carried out by polyacrylamide gel IEF followed by immunoprinting (Yuasa et al., 1986; Umetsu et al., 1989). The AHSG typing was carried out by polyacrylamide gel IEF followed by immunoblotting (Yuasa and Umetsu, 1988).

\section{RESULTS}

\section{ORM polymorphism}

In 709 serum subjects ORM1 patterns were classified into nine known phenotypes $(1,2-1,2,3-1,3-2,2 \cdot 1-1,2 \cdot 1-2,5 \cdot 2-1,5 \cdot 2-2)$ and two new rare phenotypes. Two new phenotypes were considered to be controlled by two rare ORM1 alleles, and these alleles were tentatively designated $O R M I^{*} 15$ and $O R M 1 * 16$, respectively. The ORM 115 band appears between the ORM1 8 and ORM1 4 band, and ORM1 16 band migrates between the ORM1 7 and ORM1 10 band (Fig. 1). The results of ORMl phenotyping and allele frequencies in Thai, Sri Lankan and Paraguayan populations are shown in Table 1. The distributions of ORM1 phenotypes were in a state of equilibrium based on the Hardy-Weinberg law in each of these populations (Thai, $\chi^{2}=0.1622, \mathrm{df}=1,0.50<\mathrm{p}<70$; Sri Lankan, $\chi^{2}=0.5227, \mathrm{df}=1$, $0.30<\mathrm{p}<0.50$; Paraguayan, $\chi^{2}=0.0500, \mathrm{df}=1,0.70<\mathrm{p}<0.80$ ).

On the other hand, ORM2 patterns were classified into three known phenotypes (1, 3-1, 6-1) and two new rare phenotypes. Two new phenotypes were considered to be controlled by two rare ORM2 alleles, and these alleles were tentatively designated $O R M 2 * 21$ and $O R M 2 * 22$, respectively. The ORM2 21 band appears 


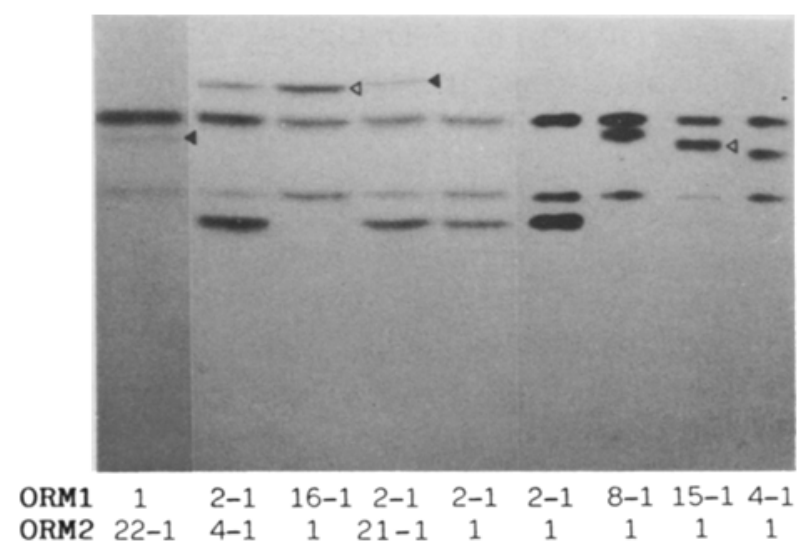

Fig. 1. Immunoprinted band patterns of several ORM types after isoelectric focusing. Anode at the top. Open and closed triangle indicate new ORM1 and ORM2 variant band, respectively.

Table 1. Distribution of ORM1 phenotypes and allele frequencies in Thai, Sri Lankan and Paraguayan populations.

\begin{tabular}{|c|c|c|c|c|c|c|}
\hline \multirow{2}{*}{ Phenotypes } & \multicolumn{2}{|c|}{ Thai } & \multicolumn{2}{|c|}{ Sri Lankan } & \multicolumn{2}{|c|}{ Paraguayan } \\
\hline & Obs. & Exp. & Obs. & Exp. & Obs. & Exp. \\
\hline 1 & 242 & 244.5 & 68 & 68.5 & 83 & 83.2 \\
\hline $2-1^{*}$ & 100 & 96.9 & 55 & 52.5 & 80 & 79.3 \\
\hline 2 & 9 & 9.6 & 8 & 10.0 & 18 & 18.9 \\
\hline $3-1$ & 0 & & 0 & & 7 & \\
\hline $3-2$ & 0 & & 0 & & 2 & \\
\hline $2 \cdot 1-1$ & 16 & & 4 & & 4 & \\
\hline $2 \cdot 1-2$ & 1 & & 2 & & 5 & \\
\hline $5 \cdot 2-1$ & 0 & 18.0 & 1 & 9.0 & 0 & 18.6 \\
\hline $5 \cdot 2-2$ & 0 & & 2 & & 0 & \\
\hline $15-1$ & 1 & & 0 & & 0 & \\
\hline $16-1$ & 0 & & 0 & & 1 & \\
\hline Others & 0 & & 0 & & 0 & \\
\hline Total & 369 & 369.0 & 140 & 140.0 & 200 & 200.0 \\
\hline \multicolumn{7}{|c|}{ Allele frequencies } \\
\hline$O R M I^{*} l$ & 0.8140 & & 0.6996 & & 0.6448 & \\
\hline$O R M I^{*} 2$ & 0.1610 & & 0.2675 & & 0.3073 & \\
\hline$O R M I^{*} 3$ & 0 & & 0 & & 0.0225 & \\
\hline$O R M 1 * 2 \cdot 1$ & 0.0236 & & 0.0221 & & 0.0230 & \\
\hline$O R M I^{*} 5 \cdot 2$ & 0 & & 0.0107 & & 0 & \\
\hline ORMl*15 & 0.0014 & & 0 & & 0 & \\
\hline$O R M I^{*} I 6$ & 0 & & 0 & & 0.0025 & \\
\hline
\end{tabular}

Obs., observed; Exp., expected. *, including two ORM1 (2/1 and 2•1/2•1) genotypes. 
between the ORM2 14 and ORM2 4 band, and ORM2 22 band migrates at a slightly cathodal position to ORM2 2 (Fig. 1). The distribution of ORM2 phenotypes and allele frequencies are shown in Table 2.

\section{AHSG polymorphism}

In 709 serum subjects, three common phenotypes, AHSG 1, 2-1 and 2, and four variant phenotypes, 3-1, 3-2, 10-1 and 10-2, were identified, which have been described previously (Yuasa and Umetsu, 1988). The distribution of AHSG phenotypes and allele frequencies in Thai, Sri Lankan and Paraguayan populations are shown in Table 3. The observed and the expected values provide a good fit to

Table 2. Distribution of ORM2 phenotypes and allele frequencies in Thai, Sri Lankan and Paraguayan populations.

\begin{tabular}{llccccc} 
Populations & $\mathrm{n}$ & \multicolumn{5}{c}{ Phenotypes } \\
\cline { 3 - 6 } & & 1 & $3-1$ & $6-1$ & $21-1$ & $22-1$ \\
\hline Thai & 369 & 363 & 0 & $6^{\mathrm{a}}$ & 0 & 0 \\
Sri Lankan & 140 & 136 & $1^{\mathrm{b}}$ & 0 & $1^{\mathrm{c}}$ & $2^{\mathrm{d}}$ \\
Paraguayan & 200 & 200 & 0 & 0 & 0 & 0
\end{tabular}

Allele frequencies: Thai, $O R M 2^{*} l=0.9919$, ORM2* $6=0.0081$; Sri Lankan, $O R M 2^{*} l=0.9857$, $O R M 2^{*} 3=0.0036, \quad O R M 2^{*} 21=0.0036, \quad O R M 2^{*} 22=0.0071 ; \quad$ Paraguayan, $O R M 2^{*} 1=1.0000$. a ORM1 2-1(3), ORM1 2(3); b ORM1 1; ${ }^{c}$ ORM1 2-1; d ORM1 1.

Table 3. Distribution of AHSG phenotypes and allele frequencies in Thai, Sri Lankan and Paraguayan populations.

\begin{tabular}{|c|c|c|c|c|c|c|}
\hline \multirow{2}{*}{ Phenotypes } & \multicolumn{2}{|c|}{ Thai } & \multicolumn{2}{|c|}{ Sri Lankan } & \multicolumn{2}{|c|}{ Paraguayan } \\
\hline & Obs. & Exp. & Obs. & Exp. & Obs. & Exp. \\
\hline 1 & 154 & 151.0 & 95 & 93.7 & 61 & 62.7 \\
\hline $2-1$ & 164 & 169.2 & 38 & 40.9 & 98 & 94.6 \\
\hline 2 & 51 & 47.9 & 6 & 4.5 & 34 & 35.7 \\
\hline $3-1$ & 0 & & 0 & & 2 & \\
\hline $3-2$ & 0 & & 0 & & 1 & \\
\hline $10-1$ & 0 & 0.0 & 1 & 1.0 & 2 & 6.9 \\
\hline $10-2$ & 0 & & 0 & & 2 & \\
\hline Others & 0 & & 0 & & 0 & \\
\hline Total & 369 & 369.1 & 140 & 140.1 & 200 & 199.9 \\
\hline \multicolumn{7}{|c|}{ Allele frequencies } \\
\hline$A H S G^{*} 1$ & 0.6396 & & 0.8179 & & 0.5600 & \\
\hline$A H S G^{*} 2$ & 0.3604 & & 0.1786 & & 0.4225 & \\
\hline$A H S G^{*} 3$ & 0 & & 0 & & 0.0075 & \\
\hline$A H S G^{*} 10$ & 0 & & 0,0036 & & 0.0100 & \\
\hline
\end{tabular}


the Hardy-Weinberg equilibrium in each of these populations (Thai, $\chi^{2}=0.4200$, $\mathrm{df}=1,0.50<\mathrm{p}<0.70$; Sri Lankan, $\chi^{2}=0.7237$, $\mathrm{df}=1,0.30<\mathrm{p}<0.50$; Paraguayan, $\left.\chi^{2}=0.2507, \mathrm{df}=1,0.70<\mathrm{p}<0.80\right)$.

\section{DISCUSSION}

Tables 4 and 5 summarize ORM1 and ORM2 allele frequencies in various populations, respectively. The frequency of duplicated allele, $O R M 1^{* 2} \cdot 1$, in the Japanese populations is around 0.16 (Yuasa et al., 1988). In contrast with Japanese, the $O R M 1 * 2 \cdot 1$ allele frequencies in Thai, Sri Lankan, and Paraguayan are fairly low as those in Filipino (Umetsu et al., 1988b), Libyan (Sebetan and Sagisaka, 1988) and German populations (Umetsu et al., 1989). The $O R M 2^{*} 6$ allele frequency in Thai population was 0.008 . It was much less than those in Japanese (Yuasa et al., 1988) and Taiwanese (Umetsu et al., 1988a). The higher frequency of $O R M 1^{* 2.1}$ and $O R M 2 * 6$ are likely to be characteristic of northern part of Mongoloid populations. It is very interesting that the $O R M 1^{* 5.2}$ and the $O R M 2^{*} 3$ alleles in the Sri Lankan population were indistinguishable from those observed in the Taiwanese and Japanese populations (Umetsu et al., 1988a; Yuasa et al., 1988).

In the ORM polymorphisms in Thai, Sri Lankan and Paraguayan, several rare ORM variants were detected, four of which were newly found and named ORM1 15, ORM1 16, ORM2 21 and ORM2 22. Future studies are needed to clarify the geographical origins and distributions of these variants.

Table 4 ORM1 allele frequencies in different populations.

\begin{tabular}{|c|c|c|c|c|c|c|c|}
\hline \multirow{2}{*}{\multicolumn{2}{|c|}{ Population (n) }} & \multicolumn{5}{|c|}{ Allele frequencies } & \multirow{2}{*}{ References } \\
\hline & & \multirow{2}{*}{$\frac{O R M 1^{* 1}}{0.6800}$} & \multirow{2}{*}{$\frac{O R M 1^{* 2}}{0.1525}$} & \multirow{2}{*}{$\frac{O R M I^{*} 3}{0}$} & \multirow{2}{*}{$\frac{O R M I^{*} 2 \cdot I}{0.1550}$} & \multirow{2}{*}{$\begin{array}{l}\text { Others } \\
0.0125\end{array}$} & \\
\hline Japanese & $(200)$ & & & & & & Yuasa et al. (1988) \\
\hline Taiwanese & $(200)$ & 0.7255 & 0.1805 & 0 & 0.0641 & 0.0300 & Umetsu et al. (1988a) \\
\hline Filipino & $(115)$ & 0.7904 & 0.1687 & 0 & 0.0409 & 0 & Umetsu et al. (1988b) \\
\hline Thai & (369) & 0.8140 & 0.1610 & 0 & 0.0236 & 0.0014 & The present study \\
\hline Sri Lankan & $(140)$ & 0.6996 & 0.2675 & 0 & 0.0221 & 0.0107 & The present study \\
\hline Nepalese & (141) & 0.6738 & 0.3121 & 0.0142 & - & 0 & Yuasa et al. (1986) \\
\hline Libyan & $(110)$ & 0.6500 & 0.3091 & 0.0091 & 0.0318 & 0 & $\begin{array}{l}\text { Sebetan and Sagisaka } \\
\text { (1988) }\end{array}$ \\
\hline German & (168) & 0.5625 & 0.3929 & 0.0298 & 0.0119 & 0.0030 & Umetsu et al. (1989) \\
\hline Dane & $(215)$ & 0.5810 & 0.3860 & 0.0330 & - & 0 & $\begin{array}{l}\text { Thymann and Eiberg } \\
(1986)\end{array}$ \\
\hline French & (112) & 0.5625 & 0.3884 & 0.0491 & - & 0 & Yuasa et al. (1986) \\
\hline Galician & $(218)$ & 0.555 & 0.422 & 0.023 & - & 0 & Montiel et al. (1988) \\
\hline Paraguayan & $(200)$ & 0.6448 & 0.3072 & 0.0225 & 0.0230 & 0.0025 & The present study \\
\hline USA Black & $(181)$ & 0.6160 & 0.3840 & - & - & 0 & Escallon et al. (1987b) \\
\hline
\end{tabular}

-, the allele which was not taken into consideration. 
Table 6 lists the frequencies of the AHSG alleles in various populations, which have been reported thus far. In the Asian populations the frequencies of $A H S G^{*} I$ tends to decrease from Japan to Thai (Umetsu et al., 1984; Yuasa and Umetsu, 1988; Umetsu et al., 1988b). The frequencies of $A H S G^{*} 1$ in Sri Lankans are sim-

Table 5. ORM2 allele frequencies in different populations.

\begin{tabular}{|c|c|c|c|c|c|c|}
\hline \multirow{2}{*}{\multicolumn{2}{|c|}{ Population (n) }} & \multicolumn{4}{|c|}{ Allele frequencies } & \multirow{2}{*}{ References } \\
\hline & & $O R M 2 * 1$ & $O R M 2 * 3$ & $O R M 2^{*} 6$ & Others & \\
\hline Japanese & $(498)$ & 0.9678 & 0.0050 & 0.0231 & 0.0040 & Yuasa et al. (1988) \\
\hline Japanese & $(400)$ & 0.9637 & 0.0025 & 0.0326 & 0.0013 & Umetsu et al. (1988a) \\
\hline Taiwanese & $(200)$ & 0.9475 & 0.0050 & 0.0450 & 0.0025 & Umetsu et al. (1988a) \\
\hline Filipino & $(115)$ & 1.0000 & 0 & 0 & 0 & Umetsu et al. (1988b) \\
\hline Thai & $(369)$ & 0.9919 & 0 & 0.0081 & 0 & The present study \\
\hline Sri Lankan & $(140)$ & 0.9857 & 0.0036 & 0 & 0.0107 & The present study \\
\hline Libyan & $(110)$ & 0.9816 & 0 & 0 & 0.0184 & Sebetan and Sagisaka (1988) \\
\hline German & $(272)$ & 0.9963 & 0 & 0 & 0.0037 & Weidinger et al. (1987) \\
\hline German & $(168)$ & 0.9970 & 0 & 0 & 0.0030 & Umetsu et al. (1989) \\
\hline Paraguayan & $(200)$ & 1.0000 & 0 & 0 & 0 & The present study \\
\hline
\end{tabular}

Table 6. AHSG allele requencies in different populations.

\begin{tabular}{|c|c|c|c|c|c|c|c|}
\hline \multirow{2}{*}{\multicolumn{2}{|c|}{ Population (n) }} & \multicolumn{5}{|c|}{ Allele frequencies } & \multirow{2}{*}{ References } \\
\hline & & \multirow{2}{*}{$\frac{A H S G^{*} I}{0.7356}$} & \multirow{2}{*}{$\frac{A H S G^{* 2} 2}{0.2639}$} & \multirow{2}{*}{$\frac{A H S G^{*} 3}{0}$} & \multirow{2}{*}{$\frac{A H S G^{*} 10}{0}$} & \multirow{2}{*}{$\frac{\text { Others }}{0.0005}$} & \\
\hline Japanese & $(2,050)$ & & & & & & Umetsu et al.(1984) \\
\hline Taiwanese & $(199)$ & 0.7286 & 0.2714 & 0 & 0 & 0 & $\begin{array}{l}\text { Yuasa and Umetsu } \\
(1988)\end{array}$ \\
\hline Filipino & $(115)$ & 0.6870 & 0.3130 & 0 & 0 & 0 & Umetsu et al. (1988b) \\
\hline Thai & $(369)$ & 0.6396 & 0.3604 & 0 & 0 & 0 & The present study \\
\hline Sri Lankan & $(140)$ & 0.8179 & 0.1786 & 0 & 0.0036 & 0 & The present study \\
\hline Nepalese & $(140)$ & 0.7571 & 0.2429 & 0 & 0 & 0 & Yuasa et al. (1985) \\
\hline \multicolumn{2}{|c|}{ Indian/Pakistani (205) } & 0.8073 & 0.1878 & 0.0049 & 0 & 0 & $\begin{array}{l}\text { Westwood et al. } \\
\text { (1987a) }\end{array}$ \\
\hline Libyan & $(110)$ & 0.8364 & 0.1636 & 0 & 0 & 0 & $\begin{array}{l}\text { Sebetan and Heshmat } \\
(1988)\end{array}$ \\
\hline German & $(344)$ & 0.6642 & 0.3208 & 0.0058 & 0.0020 & 0.0072 & Weidinger (1986) \\
\hline French & $(240)$ & 0.7167 & 0.2750 & 0.0042 & 0 & 0.0042 & $\begin{array}{l}\text { Robinet-Lévy et al. } \\
(1988)\end{array}$ \\
\hline Canadian & $(215)$ & 0.6419 & 0.3535 & 0.0046 & 0 & 0 & Cox et al. (1986) \\
\hline Paraguayan & $(200)$ & 0.5600 & 0.4225 & 0.0075 & 0.0100 & 0 & The present study \\
\hline Afro-Caribbean & n (119) & 0.6597 & 0.2353 & 0 & 0.0966 & 0.0084 & Westwood et al. (1987) \\
\hline
\end{tabular}


ilar to those in Libyan (Sebetan and Heshmat, 1988) and Indian-Pakistani (Westwood et al., 1987a). These populations show the highest frequency for $A H S G^{*} I$ in all the populations studied thus far. The Paraguayan population was characterized by the especially low $A H S G^{*} l$ frequency as compared with all other population studied thus far. The $A H S G^{*} 5$ was not detected in the present study, while this allele was not infrequent in the Japanese (Yuasa and Umetsu, 1988). AHSG*5 may be a genetic marker specific for Japanese. The $A H S G^{*} 10$ in the Paraguayan is suggestive of some Black influence (Cox et al., 1986; Westwood et al., 1987b).

It appears from the above that the data on ORM and AHSG in various populations may contribute significantly to an understanding of the genetic structure of the populations.

\section{REFERENCES}

Anderson, N.L. and Anderson, N.G. 1977. High resolution two-dimensional electrophoresis of human plasma proteins. Proc. Natl. Acad. Sci. U.S.A. 74: 5421-5425.

Cox, D.W. and Andrews, B.J. 1983. Silver stain immunofixation for $\alpha_{2}$ HS-glycoprotein: a new method for detection of protein heterogeneity. In Electrophoresis '82, Stathakos, D., ed., Walter de Gruyter, Berlin, pp. 243-247.

Cox, D.W., Andrews, B.J, and Wills, D.E. 1986. Genetic polymorphism of $\alpha_{2}$ HS-glycoprotein. Am. J. Hum. Genet. 38: 699-706.

Escallon, M.H., Ferrell, R.E. and Kamboh, M.I. 1987. Genetic studies of low-abundance human plasma proteins. V. Evidence for a second orosomucoid structural locus (ORM2) expressed in plasma. Am. J. Hum. Genet. 41: 418-427.

Johnson, A.M., Schmid, K. and Alper, C.A. 1969. Inheritance of human $\alpha_{1}$-acid glycoprotein (orosomucoid) variants. J. Clin. Invest. 48: 2293-2299.

Montiel, M.D., Carracedo, A., Lopez-Rodriguez, I., Rodriguez-Calvo, M.S., Blazquez-Caeiro, J.L. and Concheiro, L. 1988. Correlation between native and desialyzed forms of orosomucoid. Hum. Hered. 38: 353-358.

Robinet-Lévy, M., Yuasa, I., Umetsu, K. and Ikebuchi, J. 1988. Genetic polymorphism of $a_{2}$ HSglycoprotein in a French populations. Hum. Hered. 38: 174-177.

Sebetan, I.M. and Heshmat, M.M. 1988. Genetic polymorphism of desialyzed alpha 2 HS-glycoprotein by ultrathin isoelectric focusing. Z. Rechtsmed. 101: 205-207.

Sebetan, I.M. and Sagisaka, K. 1988. Genetic polymorphism of orosomucoid ORM1 and ORM2 in Libyans: Occurrence of $O R M I^{*} 2.1$ and three new ORM2 alleles. Jpn. J. Human Genet. 33: $439-443$.

Tsuge, A., Uda, H. and Ishimoto, G. 1987. A family study on serum orosomucoid polymorphism: A report of some variants, including a silent allele. Jpn. J. Legal Med. 41: 408-411.

Thymann, M. and Eiberg, H. 1986. Orosomucoid polymorphism: Determination by separator isoelectric focusing and demonstration of ORM*F subtypes. In Advances in Forensic HaemoGenetics 1, Brinkmann, B. and Henningsen, K., eds., Springer-Verlag, Berlin, pp. 162-166.

Umetsu, K., Kashimura, S., Ikeda, N. and Suzuki, T. 1983. Classification of $\alpha_{2}$-HS-glycoprotein $\left(\alpha_{2} \mathrm{HS}\right)$ types by isoelectric focusing. Z. Rechtsmed. 91:33-35.

Umetsu, K., Kashimura, S., Ikeda, N. and Suzuki, T. 1984. A new $\alpha_{2}$ HS-glycoprotein allele $\left(A H S^{*} 5\right)$ in two Japanese families. Hum. Genet. 68: 264-265.

Umetsu, K., Yuasa, I., Taketa, K. and Suzuki, T. 1987. Alpha-1-antitrypsin and orosomucoid phenotyping using allo A lectin-peroxidase for detection. Electrophoresis 8: 333-334.

Umetsu, K., Yuasa, I., Chen, E.-G., Kudo, T. and Suzuki, T. 1988a. Orosomucoid 1 and oroso- 
mucoid 2 types in the Taiwanese and Japanese: Evidence for five new orosomucoid variants. Electrophoresis 9: 224-226.

Umetsu, K., Yuasa, I., Nishimura, H., Sasaki, T. and Suzuki, T. 1988b. Genetic polymorphism of orosomucoid and alpha-2-HS-glycoprotein in a Philippine population. Hum. Hered. 38: 287-290.

Umetsu, K., Yuasa, I., Nishi, K., Brinkmann, B. and Suzuki, T. 1989. Orosomucoid (ORM) typing by isoelectric focusing: Description of two new alleles in a German population and thermostability in bloodstains. Z. Rechtsmed. 102: 171-177.

Weidinger, S. 1986. Isoelektrische Fokussierung und Printimmunfixation: ein schnelles Verfahren zur Typisierung des Alpha-2-HS-glykoproteins. In Elektrophorese Forum '86, Radola, B.J., ed., Technische Universität München, München, pp. 156-162.

Weidinger, S., Müller, T., Schwarzfischer, F. and Cleve, H. 1987. Three new orosomucoid (ORM) variants revealed by isoelectric focusing and print immunofixation. Hum. Genet. 77: 286288.

Westwood, S.A., Seaman, P.J., O'Brien, C. and Thorogood, L.J. 1987a. The phenotypic frequencies of group specific component and $\alpha$-2-HS-glycoprotein in three ethnic groups. The use of these proteins as racial markers in forensic biology. Forens. Sci. Int. 35: 197-207.

Westwood, S.A., Seaman, P.J., Ablett, P.J., Yuasa, I., Weidinger, S. and Umetsu, K. 1987b. $A 2 H S^{*} 11$ : A new allele of alpha-2-HS-glycoprotein found in Afro-Caribbeans. Electrophoresis 8: $559-561$.

Yuasa, I., Taira, T., Suenaga, K., Ito, K. and Okada, K. 1985. Determination of $\alpha_{2}$ HS-glycoprotein phenotypes by isoelectric focusing and immunoblotting: Polymorphic occurrence of $H S G A^{* 5}$ in Okinawa. Hum. Genet. $70: 32-34$.

Yuasa, I., Umetsu, K., Suenaga, K. and Robinet-Lévy, M. 1986. Orosomucoid (ORM) typing by isoelectric focusing: Evidence for two structural loci ORM1 and ORM2. Hum. Genet. 74: $160-161$.

Yuasa, I., Suenaga, K., Umetsu, K., Ito, K. and Robinet-Lévy, M. 1987. Orosomucoid (ORM) typing by isoelectric focusing: Evidence for gene duplication of ORM1 and genetic polymorphism of ORM2. Hum. Genet. 77: 255-258.

Yuasa, I. and Umetsu, K. 1988. Genetic polymorphism of human $\alpha_{2} \mathrm{HS}$-glycoprotein: Characterization and application to forensic hemogenetics. Electrophoresis 9 : 404-410.

Yuasa, I., Umetsu, K. and Suenaga, K. 1988. Orosomucoid (ORM) typing by isoelectric focusing. Evidence for additional duplicated ORM1 locus haplotype and close linkage of two ORM loci. Am. J. Hum. Genet. 43: 165-169. 